\title{
Karakteristik Edible Film Berbahan Dasar Ekstrak Karagenan dari Alga Merah (Eucheuma Spinosum)
}

\author{
Ani Nurmilla * , Hilda Aprillia W \\ Islam Bandung, Indonesia. \\ *ani_nurmilla@yahoo.co.id, hilda.apilia@gmail.com
}

Prodi Farmasi, Fakultas Matematika dan Ilmu Pengetahuan Alam, Universitas

\begin{abstract}
Nowadays, edible film is a food coating film that has been developed as a food wrapper. The main components for edible film include carrageenan, starch and pectin. This study aims to isolate carrageenan from red algae and find the best edible film formula from red algal carrageenan. Carrageenan was isolated using $\mathrm{NaOH}$ solution of various concentrations of $0.5 ; 1,0 ; 1.5$ and $2.0 \mathrm{~N}$. Carrageenan which has the best characteristics is then made into an edible film with the addition of glycerol as a plasticizer. Edible film formula is made with four variations of carrageenan concentration, i.e. 1; 1,5;2 and 2.5\%. The results of carrageenan isolation produced the best yield using $2 \mathrm{~N} \mathrm{NaOH}$, which was $8.4 \%$. The best edible film is edible film made from carrageenan $2.5 \%$ because it has the best percent elongation of $77 \%$.
\end{abstract}

Keywords: Eucheuma Spinosum, Natrium Hidroksida, carragenant.

Abstrak. Edible film merupakan film penyalut makanan yang banyak dikembangkan akhir-akhir ini sebagai pembungkus makanan. Komponen utama penyusun edible film diantaranya adalah karageenan, pati dan pektin. Penelitian ini bertujuan untuk mengisolasi karagenan dari alga merah dan mencari formula edible film dari karagenan alga merah yang paling baik. Karagenan diisolasi dengan menggunakan larutan $\mathrm{NaOH}$ berbagai konsentrasi yaitu 0,$5 ; 1,0 ; 1,5$ dan 2,0 N. Karagenan yang memiliki karakteristik paling baik kemudian dibuat menjadi edible film dengan tambahan gliserol sebagai plastisizer. Formula edible film dibuat dengan empat variasi konsentrasi karagenan, yaitu 1; 1,5;2 dan 2,5\%. Hasil isolasi karagenan menghasilkan yield yang paling baik menggunakan $\mathrm{NaOH} 2 \mathrm{~N}$, yaitu sebesar $8,4 \%$. Edible film yang paling baik adalah edible film yang dibuat dari karagenan 2,5\% karena memiliki persen pemanjangan yang paling baik yaitu $77 \%$.

Kata Kunci: Eucheuma Spinosum, Natrium Hidroksida, Karagenan 


\section{A. Pendahuluan}

Kemasan yang banyak digunakan biasanya terbuat dari bahan plastik atau disebut pengemas sintetis. Selain itu, pengemas sintetis tidak dapat didegradasi secara alami sehingga dapat menimbulkan limbah dan tidak ramah lingkungan. Oleh karena itu, diperlukan alternatif bahan pengemas yang tidak merugikan, seperti edible film yang biodegradable sehingga dapat mengurangi limbah serta ramah lingkungan.

Edible film merupakan lapisan tipis yang digunakan untuk melapisi makanan (coating), atau diletakkan di antara komponen yang berfungsi sebagai penahan terhadap transfer massa seperti air, oksigen, dan lemak (Krochta dan Johnston, 1997).

Keuntungan edible film antara lain dapat dikonsumsi langsung bersama produk yang dikemas, tidak mencemari lingkungan, memperbaiki sifat organoleptik produk yang dikemas, berfungsi sebagai suplemen penambah nutrisi, sebagai flavour, pewarna, zat anti mikroba, dan antioksidan (Murdianto, 2005).

Alga merah (Rhodophyceae) dikenal sebagai sumber utama karagenan dan agar. Rumput laut merah mempunyai kandungan koloid utama adalah karagenan dan agar. Karagenan lebih dikenal sebagai asam karagenik. Koloid karagenan dalam bentuk derivat garam dinamakan karagenat terdiri dari potasium karagenat dan kalsium karagenat (Kadi, 2004).

Penggunaan karagenan dari alga merah (Eucheuma spinosum) karena alga tersebut menghasilkan jenis karagenan lota, dimana jenis ini mempunyai kelebihan dapat membentuk edible film yang tahan lama dan elastis dibandingkan dengan jenis karagenan lainnya seperti kappa dan lambda yang dihasilkan oleh Eucheuma cottoni yang mempunyai struktur karagenan yang mudah rapuh (Necas dan Bortasikova, 2013).perbanyakan secara vegetatif berlangsung tanpa melalui perkawinan. Setiap bagian rumput laut yang dipotong akan tumbuh menjadi rumput muda yang mempunyai sifat seperti induknya.

\section{B. Landasan Teori}

\section{Jenis-Jenis Karagenan}

Karagenan dibagi menjadi tiga jenis yaitu sebagai berikut :

1. Kapa-karagenan

Kapa-karagenan dihasilkan melalui proses alkali dari hasil eliminasi $\mu$-karagenan (Jouanneau, et. al., 2010), diisolasi terutama dari rumput laut tropis yaitu Kappaphycus alvarezii (Eucheuma cottonii). Sifat-sifat kapa-karagenan adalah larut dalam air panas, dan tidak dapat larut dalam pelarut organik.

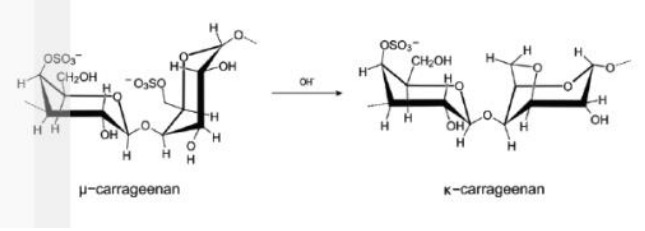

Gambar 1. Struktur kimia kapa-karagenan (Necas dan Bartosikova, 2013)

2. lota-karagenan

Iota-karagenan dihasilkan dengan proses alkali merupakan eliminasi karagenan, diisolasi terutama dari spesies Eucheuma denticulatum (E. spinosum). Strukturnya tersusun atas gugus ester 4-sulfat pada semua gugus D-galaktosa dan gugus ester 2-sulfat dalam 3,6-anhidroD-galaktosa. Ketidakberaturan gugus ester 6-sulfat digantikan gugus ester 4-sulfat dalam Dgalaktosa (Necas dan Bortasikova, 2013). Sifat-sifat iota-karagenan adalah tiksotropik, larut dalam air panas, dan tidak larut dalam pelarut organik. 


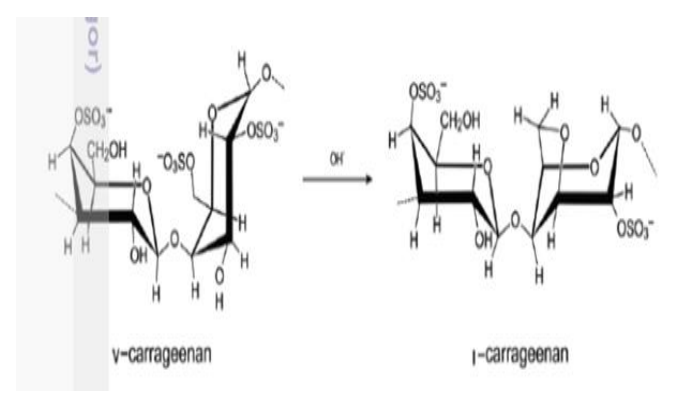

Gambar 2. Struktur kimia iota-karagenan (Necas dan Bartosikova, 2013)

\section{Lamda-karagenan}

Lamda-karagenan hasil isolasi terutama dari Chondrus crispus, dikonversi $\theta$ carrageenan (theta-carrageenan) oleh eliminasi alkali. Karagenan jenis lamda mengandung residu disulfat-D-galaktosa dan sejumlah gugus ester 2-sulfat tetapi tidak mengandung gugus ester 4-sulfat. Sifat-sifat lamda karagenan yaitu larutannya bersifat pseudo-plastic non-gel dalam air, larut dalam air dingin sebagian, dan larut dengan sempurna.
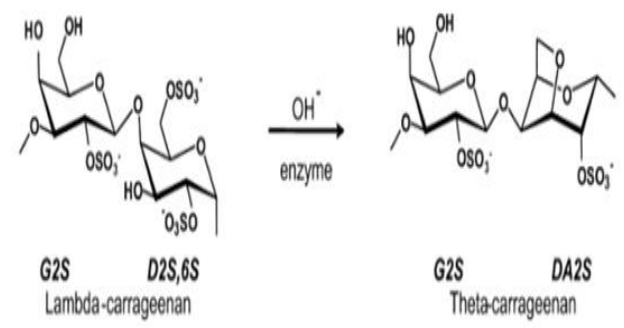

Gambar 3. Struktur kimia lambda-karagenan (Necas dan Bartosikova, 2013)

\section{Edible Film}

Edible film merupakan lapisan tipis yang terbuat dari bahan yang dapat dimakan sebagai bahan pengemas atau pelapis produk makanan. Edible film berfungsi sebagai penghalang (barrier) terhadap massa (kelembaban, oksigen, cahaya, gas volatil, lipida, zat terlarut), pembawa aditif, vitamin, mineral, antioksidan, antimikroba, pengawet, bahan untuk memperbaiki rasa dan warna produk yang dikemas) serta memudahkan penanganan makanan dan berfungsi melindungi makanan dari kerusakan fisik, kimia, dan mikrobiologi (Dangaran, and Krocha 2004).

\section{Fungsi Edible Film}

Fungsi dari edible film sebagai penghambat perpindahan uap air, menghambat pertukaran gas, mencegah kehilangan aroma, mencegah perpindahan lemak, meningkatkan karakteristik fisik, dan sebagai pembawa zat aditif. Edible film yang terbuat dari lipida dan juga film dua lapis (bilayer) ataupun campuran yang terbuat dari lipida dan protein atau polisakarida pada umumya baik digunakan sebagai penghambat perpindahan uap air dibandingkn dengan edible film yang terbuat dari protein dan polisakarida dikarenakan lebih bersifat hidrofobik (Lee and Wan, 2006 dalam Hui, 2006).

\section{Metodologi}

Tahap pertama dilakukan pengumpulan bahan. Bahan penelitian yang akan digunakan berupa alga merah (Eucheuma spinosum), diperoleh dari Pantai Bagolo, Jawa Barat, kemudian dideterminasi di Herbarium Jatinangor Laboratorium Taksonomi Tumbuhan Departemen Biologi FMIPA UNPAD. Penyiapan simplisia alga merah dilakukan mengumpulkan alga merah, kemudian dilanjutkan dengan sortasi basah, pencucian, pengecilan ukuran, pengeringan, sortasi kering, sehingga diperoleh simplisia alga merah. Simplisia yang sudah didapat selanjutnya dilakukan ekstraksi meggunakan $\mathrm{NaOH}$ berbagai konsentrasi sehingga diperoleh 
karagenan. Hasil ekstraksi karagenan yang diperoleh dilakukan karakterisasi karagenan meliputi uji viskositas, $\mathrm{pH}$, kadar abu dan kadar air. Karagenan yang memenuhi syarat karakterisasi selanjutnya digunakan untuk optimasi formula edible film. Penentuan formula dilakukan dengan membuat lima formula edible film dengan komponen penyusun karagenan, CMC-Na, gliserol dan aquadest. Optimasi formula dilakukan dengan menentukan variasi konsentrasi karagenan yaitu $1 ; 1,5 ; 2 ; 2,5 \% \mathrm{~b} / \mathrm{v}$.

Hasil optimasi formula edible film karagenan dari alga merah (Eucheuma spinosum) yang baik akan menjadi dasar pembuatan edible film karagenan alga merah kemudian dilakukan karakterisasi edible film yang meliputi uji ketebalan film, kuat tarik dan pemanjangan. Uji karakterisasi edible film dilakukan di Balai Besar Tekstil. Formulasi edible film yang paling baik kemudian ditentukan berdasarkan hasil konsentrasi yang paling memenuhi syarat.

\section{Hasil Penelitian dan Pembahasan Ekstrasi Karagenan}

Proses ekstraksi karagenan dilakukan selama 2 jam pada suhu $80-90^{\circ} \mathrm{C}$ menggunakan pelarut $\mathrm{NaOH}$ dengan berbagai konsentrasi $0,5 \mathrm{~N} ; 1 \mathrm{~N} ; 1,5 \mathrm{~N} ; 2 \mathrm{~N}$. Berdasarkan penelitian Huda (2012), kenaikan suhu ekstraksi meningkatkan rendemen karagenan, tetapi pada suhu lebih dari $90^{\circ} \mathrm{C}$ maka rendemen karagenan akan mengalami penurunan. Begitu juga dengan waktu ekstraksi, rendemen karagenan akan semakin besar, hal ini disebabkan semakin lama rumput laut berinteraksi dengan panas dan larutan pengekstrak, maka akan semakin banyak karagenan yang terlepas dari dinding sel dan menyebabkan struktur karagenan menjadi rusak sehingga menurunkan rendemen karagenan. Rumput laut sebanyak $7 \mathrm{~g}$ direndam dalam aquades selama 15 menit, perendaman ini bertujuan agar membersihkan rumput laut dan membuat rumput laut mengembang karena menyerap air sehingga dapat mempercepat proses keluarnya karagenan pada proses ekstraksi, dan dapat menghilangkan bau dari rumput laut, kemudian rumput laut diekstrak dengan menggunakan pelarut $\mathrm{NaOH}$

dengan berbagai konsentrasi $0,5 \mathrm{~N} ; 1 \mathrm{~N} ; 1,5 \mathrm{~N} ; 2 \mathrm{~N}$.

Rendemen karagenan yag dihasilkan dari konsentrasi $0,5 \mathrm{~N} ; 1 \mathrm{~N} ; 1,5 \mathrm{~N} ; 2 \mathrm{~N}$ berturut-turut adalah $6,22 \% \mathrm{~b} / \mathrm{b} ; 6,4 \% \mathrm{~b} / \mathrm{b} ; 7,2 \% \mathrm{~b} / \mathrm{b} ; 8,4 \% \mathrm{~b} / \mathrm{b}$. Rendemen karagenan terendah terdapat pada konsentrasi $0,5 \mathrm{~N}$ sedangkan konsentrasi karagenan tertinggi terdapat pada konsentrasi 2 N.

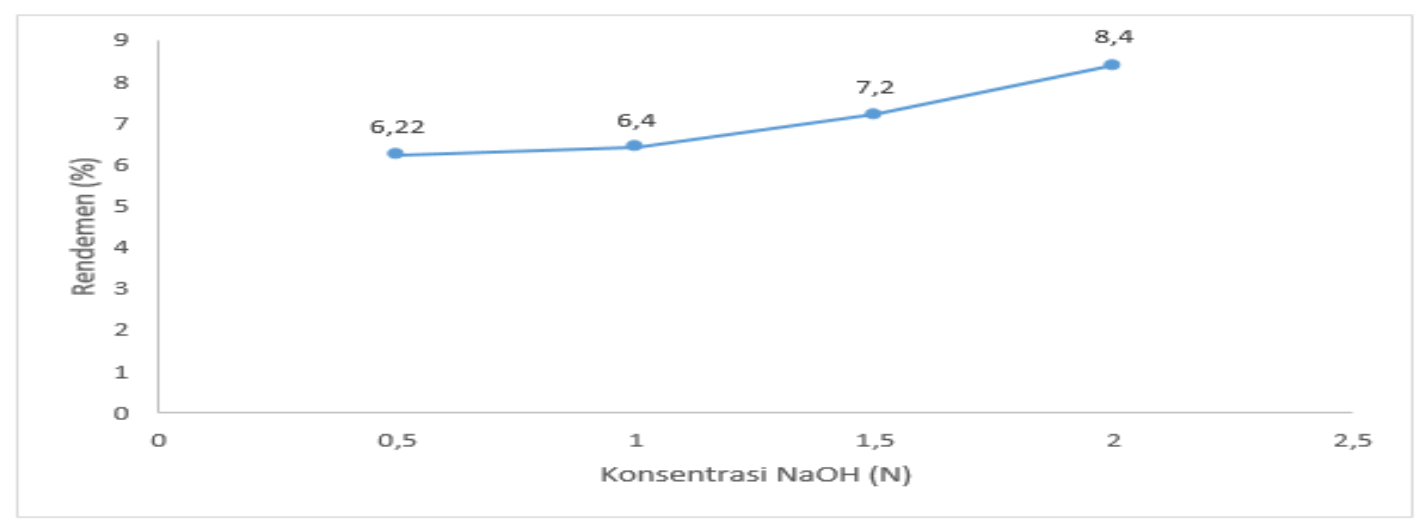

Gambar 4. Hubungan antara rendeman (\%) karagenan dengan konsentrasi $\mathrm{NaOH}$

Pada hasil penelitian ini karagenan meningkat dengan bertambahnya konsentrasi $\mathrm{NaOH}$. Hal ini disebabkan oleh konsentrasi basa yang tinggi yang dapat memecah dinding sel alga (Fardhyanti, 2015).

\section{Karakteristik Karagenan}

\section{Viskositas}

Pengujian viskositas dilakukan untuk mengetahui kekentalan karagenan sebagai konsentrasi JRF is licensed under Creative Commons AtributionRiset Farmasi 
pada suhu tertentu (Wenno, 2009). Pengujian viskositas dilakukan menggunakan alat viskometer Brookfield dengan spindel no 3 pada kecepatan $30 \mathrm{rpm}$. Pengujian viskositas dilakukan untuk mengetahui tingkat kekentalan karagenan sebagai larutan pada konsentrasi dan suhu tertentu (Wenno et al., 2012). Hasil pengujian viskositas karagenan dari konsentrasi 0,5 $\mathrm{N} ; 1 \mathrm{~N} ; 1,5 \mathrm{~N} ; 2 \mathrm{~N}$ berturut-turut adalah $25,60 \mathrm{cP} ; 30,68 \mathrm{cP} ; 33,30 \mathrm{cP} ; 34,85 \mathrm{cP}$. Hasil analisis keragenan menunjukkan bahwa perlakuan konsentrasi $\mathrm{NaOH}$ berpengaruh nyata terhadap viskositas, dimana nilai viskositas meningkat seiring dengan meningkatnya konsentrasi $\mathrm{NaOH}$. Hal ini sejalan dengan Anwar, et al. (2013) bahwa tingginya konsentrasi $\mathrm{NaOH}$ maka dapat melarutkan garam-garam yang terkandung dalam rumput laut sehingga viskositas dapat meningkat. Viskositas larutan karagenan akan menurun seiring dengan peningkatan suhu sehingga terjadi depolimerisasi yang kemudian dilanjutkan dengan degradasi karagenan (Towle, 1973 dalam Wenno, et al., 2012). Menurut standarisasi karagenan komersial syarat mutu nilai viskositas minimum $5 \mathrm{cP}$ maka karagenan yang dihasilkan dalam penelitian ini telah memenuhi syarat mutu.

Tabel 1. Data hasil viskositas karagenan

\begin{tabular}{|c|c|c|c|}
\hline \multicolumn{4}{|c|}{ Viskositas (Cp) } \\
\hline Karagenan A & Karagenan B & Karagenan $\mathrm{C}$ & Karagenan D \\
\hline 25,60 & 30,68 & 33,3 & 34,85 \\
\hline
\end{tabular}

pH

Hasil pengujian $\mathrm{pH}$ menunjukan sampel karagenan tidak memenuhi persyaratan karena memiliki nilai $\mathrm{pH} 10$. Menurut literatur $\mathrm{pH}$ yang memenuhi syarat memiliki rentang nilai $\mathrm{pH} 9$ - 9,5. Nilai pH tergantung dari konsentrasi pelarut alkali yang ditambahkan. Faktor yang mempengaruhi nilai $\mathrm{pH}$ tidak memenuhi syarat dikarenakan semakin tinggi konsentrasi $\mathrm{NaOH}$ selama proses alkalisasi berlangsung, menyebabkan pHnya semakin tinggi sehingga kemampuan $\mathrm{NaOH}$ dalam mengekstrak semakin besar.

Tabel 2. Nilai $\mathrm{pH}$

\begin{tabular}{|c|c|}
\hline pH & Nilai pH \\
\hline Karagenan $\mathrm{A}$ & 10,3 \\
\hline Karagenan B & 10,3 \\
\hline Karagenan $\mathrm{C}$ & 10,4 \\
\hline Karagenan D & 10,5 \\
\hline
\end{tabular}

\section{Kadar Air}

Kadar air karagenan memiliki peran penting terhadap stabilitas produk yang dilapisinya. Oleh karena itu karagenan diharapkan memiliki kadar air yang rendah sehingga dalam penerapannya sebagai kemasan primer tidak memberi sumbangan air kepada produk yang akan berdampak pada kerusakan produk dan penurunan masa simpan.

Analisis kadar air bertujuan untuk mengetahui seberapa besar kandungan air yang masih tertinggal karena ini berkaitan dengan mutu dari karagenan tersebut. Hasil kadar air pada penelitian ini untuk karagenan a sebesar $10,10 \%$, untuk karagenan b sebesar 8,28 \%, untuk karagenan c sebesar 9,07\%, untuk karagenan d sebesar 8,75\%. Kadar air tertinggi terdapat pada karagenan a yaitu sebesar 10,10\% dan kadar air terendah terdapat pada karagenan b yaitu sebesar $8,28 \%$. Kadar air dengan nilai tertinggi sudah memenuhi standar FAO, dimana standar FAO untuk kadar air adalah maksimal $12 \%$. 
Tabel 3. Hasil kadar air dengan konsentrasi $\mathrm{NaOH}$

\begin{tabular}{|c|c|c|c|c|}
\hline Kadar Air & Pengujian 1 & Pengujian 2 & Rata-rata $\pm \mathrm{SD}$ & Persyaratan \\
\hline karagenan A & 10,2 & 9,97 & $10,08 \pm 0,16$ & \multirow{4}{*}{$12 \%$} \\
\hline karagenan B & 7,93 & 8,63 & $8,28 \pm 0,49$ & \\
\hline karagenan $\mathrm{C}$ & 9,09 & 9,06 & $9,07 \pm 0,02$ & \\
\hline karagenan D & 8,92 & 8,6 & $8,76 \pm 0,22$ & \\
\hline
\end{tabular}

\section{Kadar Abu}

Parameter kadar abu total memberikan gambaran kandungan mineral internal dan eksternal yang berasal dari proses awal hingga proses akhir terbentuknya simplisia (Ditjen POM 2000). Hasil penetapan kadar abu total dari karagenan yang dihasilkan dari penelitian ini adalah karagenan a sebesar 23,17 \%, karagenan b 11,04 \%, karagenan c 2,08 \%, karagenan d 9,97\%.

Standar karagenan yang telah ditetapkan oleh FAO yaitu berkisar 18-40 \% FAO (2007) dalam Hakim dkk. (2011).

Tabel 4. Hasil kadar abu karagenan

\begin{tabular}{|c|c|c|c|c|}
\hline Kadar Abu & Pengujian 1 & Pengujian 2 & Rata-rata \pm SD & Persyaratan \\
\hline karagenan $\mathrm{A}$ & 26,9 & 19,44 & $23,17 \pm 5,27$ & \\
\hline karagenan B & 19,07 & 3,02 & $11,045 \pm 11,35$ & $18-40 \%$ \\
\hline karagenan $\mathrm{C}$ & 3,785 & 0,38 & $2,08 \pm 2,41$ & \\
\hline karagenan D & 17,45 & 0,5 & $8,97 \pm 11,98$ & \\
\hline
\end{tabular}

\section{Pembuatan Edible Film Berbahan dasar Karagenan}

Bahan baku yang digunakan untuk pembuatan edible film ini yaitu karagenan hasil ekstraksi yang memiliki, hasil optimal pada proses sebelumnya. Karakteristik edible film karagenan tergantung pada berbagai faktor, antara lain sifat-sifat dan jenis karagenan, plasticizer yang digunakan, dan jenis bahan campuran. Pada penelitian ini dibuat 3 jenis edible campuran komposit karagenan, CMC-Na dan gliserol, sebagai plasticizer, serta karagenan ditambah plasticizer. Komposit karagenan merupakan komposit film yang terdiri dari komponen hidrokoloid (karagenan). Selain bahan baku, ditambahkan pula plasticizer. Plasticizer merupakan bahan yang ditambahkan ke dalam suatu bahan pembentuk film untuk meningkatkan fleksibilitasnya, karena dapat menurunkan gaya intermolekul sepanjang rantai polimernya, sehingga film akan elastis atau lentur. Plasticizer yang digunakan pada penilitian ini adalah CMC-Na dan gliserol. (McHugh dkk., 1994). dilihat Tabel.

Formulasi bahan dasar dan penambahan konsentrasi karagenan yang digunakan dapat

Tabel 5. Optimasi Formulasi pembuatan edible film

\begin{tabular}{|c|c|c|c|c|}
\hline \multirow{2}{*}{ Bahan } & \multicolumn{4}{|c|}{ Jumlah (\% ) } \\
\hline & F1 & F2 & F3 & F4 \\
\hline Karagenan & 1 & 1,5 & 2 & 2,5 \\
\hline CMC-Na & 1,5 & 1,5 & 1,5 & 1,5 \\
\hline Gliserol & 5 & 5 & 5 & 5 \\
\hline Aquades ad & 100 & 100 & 100 & 100 \\
\hline
\end{tabular}

Dalam formula tersebut penggunaan karagenan dengan konsentrasi 1 sampai 2,5 adalah untuk mengetahui, pada konsentrasi berapa yang menunjukan karagenan tersebut sudah stabil sebagai komposit dalam pembentukan edible film. Sedangkan penambahan CMC-Na dan 
gliserol sebagai plasticizer dengan konsentrasi masing-masing $1,5 \%$ dan $5 \%$ adalah berdasarkan penelitian (Harsa, dkk., 2015) dimana pada konsentrasi tersebut menunjukan bahwa CMC-Na dan gliserol telah stabil sebagai plasticizer.

\section{Karakteristik Edible Film Berbahan Dasar Karagenan}

\section{Ketebalan Film}

Ketebalan film merupakan karakteristik yang penting dalam menentukan kelayakan edible film sebagai kemasan produk pangan karena ketebalan sangat

mempengaruhi sifat fisik dan mekanik edible film lainnya, misalnya kuat tarik dan pemanjangan. Edible film yang tebal akan memberi perlindungan yang lebih baik terhadap produk pangan yang dikemas.

Edible film yang tebal akan meningkatkan kuat tarik, tetapi nilai pemanjangan dalam air akan menurun (Ariska dan Suyatno 2015). Ketebalan edible film cenderung semakin meningkat dengan pertambahan konsentrasi karagenan dan gliserol. Peningkatan konsentrasi karagenan pada pembuatan edible film menyebabkan meningkatnya padatan terlarut pada larutan pembentuk edible film sehingga ketebalan edible film yang dihasilkan semakin meningkat. Peningkatan ketebalan edible film juga terkait dengan sifat senyawa koloid yang unik sebagai pengental dan pensuspensi, dan adanya interaksi antar komponen penyusun edible film (Galus dan Lenart 2013).

Peningkatan ketebalan karena pengaruh konsentrasi gliserol juga disebabkan karena molekul gliserol akan menempati rongga dalam matriks edible film dan berinteraksi dengan molekul karagenan untuk membentuk polimer yang menyebabkan peningkatan jarak antar polimer molekul karagenan sehingga meningatkan ketebalan edible film (Sudaryati, et al. 2010).

Penambahan CMC -Na membuat larutan edible film semakin kental, setelah dioven hasil edible film yang didapatakn sedikit tebal. Semakin tebal lapisan edible film maka proses oksidasi semakin sulit terjadi, karena oksigen sulit menembus edible film tersebut.

Penambahan CMC-Na akan membuat lapisan edible film yang dihasilkan tebal dan strukturnya kaku. Semakin tebal dan kaku lapisan edible film kuat traiknya akan semakin kecil.

Ketebalan edible film yang dihasilkan pada formula $10,023 \mathrm{~mm}$, formula 2 sebesar $0,029 \mathrm{~mm}$, formula 3 sebesar $0,035 \mathrm{~mm}$, dan formula $40,026 \mathrm{~mm}$. Nilai ketebalan terendah diperoleh pada F1, sedangkan nilai ketebalan tertinggi diperoleh pada F3.

Tabel 6. data pengujian ketebalan edible film berbagai formula

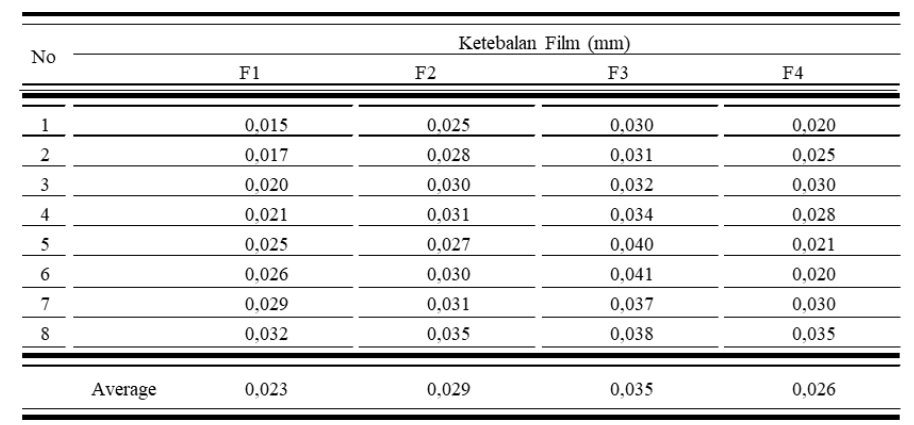

\section{Kuat Tarik}

Kuat tarik menunjukan nilai maksimum gaya yang diproduksi jika dilakukan uji tarik. Semakin tinggi gaya yang diproduksi maka kekuatan tariknya akan semakin besar. Edible film yang memiliki kekuatan tarik yang tinggi mampu melindungi produk yang dikemasnya dari gangguan mekanis dengan baik. (Suryaningrum dkk., 2005). Pada formula 1 yang merupakan campuran bahan karagenan, gliserol, dan CMC-Na pada penelitian ini memiliki nilai kuat tarik sebesar 1,17 N/mm2, sedangkan formula 2 dengan campuran bahan karagenan, gliserol, CMC$\mathrm{Na}$ memiliki kuat tarik $0,76 \mathrm{~N} / \mathrm{mm} 2$. Pada formula 3 dengan campuran bahan karagenan, gliserol CMC-Na 1,06 N/mm2 dan pada formula 4 menghasilkan nilai kuat tarik $0.98 \mathrm{~N} / \mathrm{mm} 2$. 
Hasil kuat tarik pada penelitian ini lebih tinggi apabila dibandingkan dengan penelitian Handito (2011) yang menghasilkan kuat tarik sebesar 0,89 Mpa. Secara umum nilai kuat tarik edible film yang memenuhi standar minimal nilai kuat tarik edible film berdasarkan Japanese Industrial Standart yaitu 3,92 Mpa (Ariska dan Suyatno 2015).

Tabel 7. Pengujian kuat tarik formula edible film

\begin{tabular}{|c|c|}
\hline Formula & Kuat Tarik (MPa) \\
\hline F1 & 1,17 \\
\hline F2 & 0,76 \\
\hline F3 & 1,06 \\
\hline F4 & 0,98 \\
\hline
\end{tabular}

\section{Pemanjangan}

Persentase pemanjangan merupakan persen pertambahan panjang film maksimum saat memperoleh gaya tarik sampai film putus dibandingkan dengan panjang awalnya. Persentase pemanjangan dikatakan baik jika nilainya lebih dari $50 \%$ dan dikatakan buruk jika nilainya kurang dari $10 \%$ (krochta dan De Muller-Jhonson, 1997). Persentase pemanjangan pada campuran komposit karagenan, gliserol, CMC-Na Pada formula 1 memiliki nilai sebesar 16,50. Pada formula 2 menghasilkan nilai sebesar $30 \%$, sedangkan pada formula 3 menghasilkan nilai sebesar $46 \%$, dan pada formula 4 memiliki nilai $77 \%$.

Tabel 8. Data pengujian persen pemanjangan edible film

\begin{tabular}{|c|c|}
\hline Formula & Pemanjangan (\%) \\
\hline F1 & 16,50 \\
\hline $\mathrm{F} 2$ & 30,00 \\
\hline F3 & 46,00 \\
\hline F4 & 77,00 \\
\hline
\end{tabular}

Setelah melakukan penelitian mengenai karakterisasi edible film diantaranya adalah Suryaningrum dkk., 2005 mengkaji karakteristik edible film campuran karagenan dengan tapioka sebagai plasticizer. Nurlaila dkk., 2013, meneliti karakteristik edible film dengan karagenan yang diekstraksi dengan menggunakan $\mathrm{KOH}$ dan campuran edible film yaitu dengan variasi konsentrasi karagenan menghasilkan karakteristik edible film dengan penggunaan konsentrasi karegenan 1,5\% menghasilkan edible film terbaik dengan sifat-sifat kuat tarik sebesar 5516,67 kgf/cm2, persen pemanjangan sebesar 43,05\% (Delya, dkk., 2013).

\section{Kesimpulan}

1. Berdasarkan hasil penelitian karagenan dengan konsentrasi $\mathrm{NaOH} 1 \mathrm{~N}$, dipilih karena memiliki karakteristik yang paling bagus berdasarkan parameter viskositas dengan nilai 30,68; pH 10,3; kadar air 8,28 \%.

2. Formulasi edible film dari karagenan dilihat dari karakteristik pemanjangan yang paling baik adalah formula 4 dengan nilai persen pemanjangan $77 \%$.

\section{E. Saran}

1. Perlu dilakukan uji efektifitas pengawet menggunakan makanan dibungkus dengan edible film.

2. Perlu dilakukan analisis karakteristik terhadap edible film selain kuat tarik, perpanjangan, ketebalan film. Untuk mngetahui sifat termal dari edible film, uji permebilitas, uap air (WVTR). 


\section{Daftar Pustaka}

[1] Ariska RE, Suyatno. (2015). Pengaruh konsentrasi karagenan terhadap sifat fisik dan mekanik edible flm dari pati bonggol pisang dan karagenan dengan plasticizer gliserol. Prosiding. Seminar Nasional Kimia Jurusan Kimia FMIPA Universitas Negeri Surabaya. Surabaya, 3-4 Oktober 2015.

[2] Dangaran, L.K., Renner-Nantz Krochta, J.M., (2004). Crystallization Inhibitor Effect On Rate of Gloss Fade of Whey Protein Coating. Department of Food Science and Technology. University of California.

[3] Ditjen POM. (2000). Paramter Standar Umum Ekstrak Tumbuhan Obat. Cetakan Pertama. Jakarta: Departemen Kesehatan RI.

[4] Fardhyanti, D. S., and S. S. Julianur. (2015). Karakterisasi Edible Film Berbahan Dasar Ekstrak Karagenan dari Rumput Laut (Eucheuma Cottonii). Jurnal Bahan Alam Terbarukan. 4 (2): 68-73.

[5] Food and Agriculture Organization of the United Nations (FAO). (2007). Cultured Aquatic Species Information Programme Lates calcarifer (Block, 1790). Fisheries and Aquaculture Departement

[6] Galus, S., Lenart, A. (2013). Development and characterization of composite edible flms based on sodium alginate and pectin. Journal of Food Engineering. 115(4): 459-465.

[7] Harsa, P., Dyah, T.R., Boan, T.V.H., Novie, V (2015). Pembuatan Edible Film Dari Karagenan Rumput Laut Eucheuma Cottoni Untuk Mengawetkan Buah Nanas. jurnal teknik kimia ISSN 1693-4393

[8] Hudha, M. I., Sepdwiyanti, R., Sari, S. C. (2012). Ekstraksi Karaginan dari Rumput Laut (Eucheumaspinosum) dengan Variasi Suhu Pelarut dan Waktu Operasi. Berkala Ilmiah Teknik Kimia 1(1) : 17-20.

[9] Hakim, A. R., Wibowo, S., Arfini, F., Peranginangin, R. (2011). Pengaruh Perbandingan Air Pengekstrak, Suhu Presipitasi, dan Konsentrasi Kalium

[10] Jouanneu, D., Boulenguer, P., Mazoyer, J., Helbert, W. (2011). Hybridity of carrageenans water- and alkali-extracted from Chondracanthus chamissoi, Mazzaella laminarioides, Sarcothalia crispata, and Sarcothalia radula. J. App. Phycol. 23(1): 105-114.

[11] Kadi (2004). Potensi Rumput Laut Di Beberapa Perairan Pantai Indonesia. Jurnal Oseana Volume XXIX, Nomor 4, Tahun (2004) : 25 - 36 ISSN 0216-1877.

[12] Krochta, J. M., C. De Mulder-Johnston, 1997, Edible and Biodegradable Polymer Films:Challenges and Opportunities, J. Food Tech., 51 (2), 61-74.

[13] Lee, S. Y. Wan, V.C.H. 2006. Edible Films and Edible Coatings.In Handbook of Food Science, Technology, and Engineering Volume I. (Eds) : Hui, Y.H. CRC Press, USA.

[14] Murdianto. 2005. Sifat Fisik dan Mekanik Edible Film Ekstrak Daun Janggelan. J. Agrosains. 18 (3) Juli 2005.

[15] Mc Hugh, Krochta. (1994). Sorbitol vs Gliserol Plasticized Whey Protein Edible Film: Integrated Oxygen Permeability and Tensile Strength Evaluation. J. Of Agriculture and Food Chem. 42 (4)

[16] Necas, J., Bartosikova, L. (2013). 'Carrageenan : a review, Veterinarni Medicina, pp. 187205.

[17] Pakidi, C. S., Suwoyo, H. S. (2017) Potensi Dan Pemanfaatan Bahan Aktif Alga Cokelat Sargassum Sp. Fakultas Pertanian, Universitas Musamus: Volume 6, Nomor 1, Juni 2017.

[18] Sudaryati HP, Mulyani ST, Hansyah ER. (2010). Sifat fisik dan mekanis edible film dari tepung porang (Amorphopallus oncophyllus) dan karboksimetil selulosa.Jurnal Teknologi Pertanian. 11(3): 196-201.

[19] WHO. (1999). Safety evaluation of certain food additive. International program on chemical safety. Geneva. 
[20] Wenno. MR, Thenu. JL, Lopulalan. CGC. (2012). Karakteristik Kappa Karaginan dari Kappaphycus Alvarezii pada berbagai Umur Panen. JPB Perikanan Vol. 7 No. 1: 61-67.

[21] Wenno M. R., (2009). Karakteristik Fisko-kimia Karagenan Datri Eucheuma cottoni pada Bagian Thalus, Berat Bibit dan Umur Panen 